\title{
Inventory of Pesticides and their impact on the environment by calculating the frequency of treatment indicator in the Gharb plain (Morocco)
}

\author{
Hind El Bouzaidi, Fatima Zahra Hafiane* and Mohammed Fekhaoui \\ Mohammed V University, GEOPAC center, Scientific Institute of Rabat, Morocco
}

\begin{abstract}
The Gharb area upstream of the Merja Zerga lagoon, also called the Ramsar Wetland, is a vital area with high agricultural activities, which increase the risk of contamination and pollution of air, water and soil, as well as endanger the ecological system of the area. The first survey has targeted 100 farm wells and has covered a surface of $555 \mathrm{ha}$, and the second one has targeted 71 pesticide resellers, have revealed the great uses of pesticides $(13.6 \mathrm{~kg} / \mathrm{ha})$. The data collected is helping to evaluate, by using the indicator called the Treatment Frequency Indicator (TFI), the pressure of pesticides on the environment. As a methodology, we have adopted the calculation of a pressure indicator for the use of TFI pesticides using a platform called OLYMPE, by dividing the dose applied by the user over the recommended or prescribed dose on the product, the input data is collected during field surveys. The results of the survey show that the banana is the crop that undergoes the phytosanitary treatment, registering a TFI of 38. In term of the total consumption of pesticides identified, the orange tree comes at the first place ahead of other crops practised in the study area.
\end{abstract}

Keywords: Gharb; agricultural practices; pesticides; phytosanitary pressure; treatment frequency indicator (TFI); environment.

\section{Introduction}

Morocco, with a surface of 71 million hectares, has only $12 \%$ of agricultural lands ( 9 million hectares) where $19 \%$ are irrigated ${ }^{1}$.

The dominant culture is cereals, which represent $59 \%$ of the used agricultural land, with a surface of 3.45 million hectares. Sixteen (16) \% of UAL is planted in fruit trees such as the olive tree, which covers 1,045 Mha and citrus fruits. That has known improvement in quality and quantity under an important phytosanitary treatment; vegetable crops and leguminous crops represents $6 \%$ of the total UAL. For other types of crops such as sugar crops, Morocco has recorded a plantation of 58,000 ha of sugar beet and 10,000 ha of sugar cane.

Cereals can be attacked by several pathogens, which causes diseases of wheat and could damage the entire of the none treated production. The most important Pathogens are Septoria (septoria tritici and stagonospora nodorum); Yellow rust (Puccinia striiformis); Brown Rust (Puccinia triticina). The fungal treatment of these diseases is based on two active ingredients families (triazole and strobilurins), where the Fusarium head blight can also be treated with fungicides, whose active ingredients are: (Metconazole and Prothioconazole) ${ }^{2}$.

*Corresponding author: Fatima Zahra Hafiane

Email address: f.s.h.hafiane@gmail.com

DOI: http://dx.doi.org/10.13171/mjc10402005041137fzh
Concerning the fruit trees, especially citrus fruits, the most serious and widespread diseases are virus diseases such as psorosis (psorosis A, concave gum, blind pocket), stubborn, xyloporosis, exocortis and impietratura. Although the Tristeza has only founded on Meyer lemon, certain declines of orange trees must be tested. Besides virus diseases, the ferment gum (Florida or Rio Grande gummosis) of unknown origin has founded on lemon and orange trees. Among the cryptogamic diseases, the most serious disease is due to phytophthora, which attacks trunks and fruits (gum and brown rot). The phytophthora has also founded on alternariose, melanosis (stem end rot), septoria, stylary rot (stylar end rot), Rosellinia root rot, greasy spot.

The Market Garden, like strawberry, knows several diseases such as nematodes, which are treated with methyl bromide, while the rhizome rot, the oidium and the purple spots disease are treated respectively with \{phosetyl-Al and maneb\}, \{triazole and strobilurin $\}$, and \{maneb, mancozeb, captan\}. Also, the gray mold is treated preventively with (procymidone, fenhexamide) ${ }^{3}$.

The legume sector is experiencing major damage, which affects the production and quality of products intended for human consumption. The damage due to broomrape has been reported, to beans, peas and

Received December 6, 2019

Accepted January 13, 2020

Published May 4, 2020 
lentils. Using the glyphosate as an herbicide provides reasonable pest control.

Cryptogamic diseases such as anthracnose (caused by a fungus called Ascochyta fabae (Speg)), chocolate bean spot (Botrytis fabae), powdery pea mildew, rust (Uromyces fabae) beans, are the most common nationwide and they are treated with the use of fungicides such as vinclozolin (Ronilan 50WP) or mancozeb (Dithane M45) ${ }^{4}$.

However, Morocco remains agricultural; the importance of the agricultural sector is manifested by its significant contribution to the Gross Domestic Product GDP (11\%) and job creation, particularly in rural areas where agriculture remains the main source of income and main provider of employment ${ }^{2}$.

Nevertheless, a large number of diseases, pests and weeds harm these crops and consequently reduce the quantity and quality. To control these bio-aggressors and reduce their impact on an economically tolerable threshold, several means of control are used. But, chemical control, in Morocco as everywhere else, remains the most used method.

The market supply of plant protection products for agricultural use is covered by the imports, which exceeded 28,773 tons at the end of 2016 (95\% of the local market). While the local production is around 1,500 tons, in term of turnover. The local market value is estimated at 1.5 billion dirhams ${ }^{5}$ and provided by more than 85 licensed companies operating at the national level. These companies are grouped into four groups: 23 companies belong to Crop life Morocco; 7 companies belong to ASMIPH, 23 non-affiliated companies and19 companies without Agricultural Pesticides ${ }^{6}$.

The market garden absorbs $44 \%$ of the total quantity, followed by plantations $(26 \%)$ and cereals $(21 \%)$. The rest is shared between industrial crops $(7 \%)$. By product type, insecticides represent $45 \%$ of the market, followed by fungicides $(40 \%)$ and herbicides $(15 \%)^{7}$.

The objective of this study is to contribute to the improvement of the population's health and the preservation of the environment. Its also permit to identify the pesticide formulations used by the producers.

. This study will serve to quantify the environmental nuisances generated by pesticides, which will allow us to give proposals for appropriate measures to improve the pesticide management and reduce the associated risk within an irrational use of these dangerous products.

\section{Material and methods}

\subsection{General presentation of the study area}

The plain of Gharb is located $40 \mathrm{~km}$ north of Rabat in the region of Rabat-Salé-Kenitra covers a geographical area of 616000 ha. The Plain covers the provinces of Kenitra, Sidi Slimane and Sidi Kacem ${ }^{3}$. Characterized by Mediterranean climate with an oceanic influence and temperate winter sub-humid with a semi-arid trend in the inner zone (Figure1).

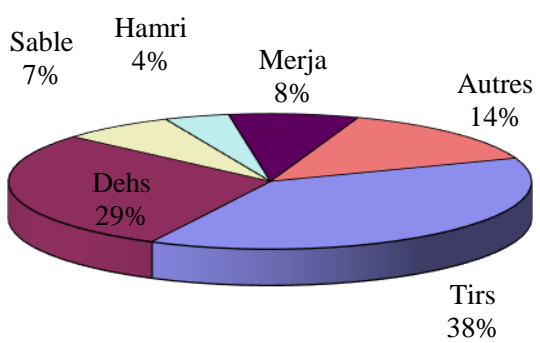

Figure 1. Soil distribution of the Gharb plain (ORMVAG,2017)

Contribution from the river of Sebou and its tributaries is estimated at 4.8 billion $\mathrm{m}^{3}$, which presents $27 \%$ of the national mobilizable water potential, of which 1.8 billion is for agriculture (Table1) and vegetable production (Table2). The groundwater is estimated at 900 million $\mathrm{m}^{3}$.

Table 1.The main dams serving the perimeter are as follows (ORMVAG, 2017).

\begin{tabular}{|c|c|c|}
\hline Dams & Date of filling & Useful capacity in Million $\mathrm{m}^{3}$ \\
\hline El Kansra & 1935 & 216 \\
\hline Idriss 1 & 1973 & 1130 \\
\hline Allal Fassi & 1991 & 64 \\
\hline Al wahda & 1997 & 3522 \\
\hline
\end{tabular}


Table 2. Emblavements and productions of the agricultural campaign (2015/2016) (ORMVAG, 2017).

\begin{tabular}{|c|c|c|}
\hline Cultures & Area (ha) & Production $(1000 \mathrm{~T})$ \\
\hline Fall cereals & 209878 & 292 \\
\hline Rice & 5935 & 45 \\
\hline Sugar culture & 17895 & 995 \\
\hline - Beet & 13108 & 687 \\
\hline - Sugar cane & 4787 & 309 \\
\hline Citrus & 20595 & 317 \\
\hline Seasonal market gardening including: & 27178 & 801 \\
\hline - Industrial tomato & 360 & 30 \\
\hline - Artichoke & 2230 & 31 \\
\hline Oilseeds including : & 40806 & 38 \\
\hline - Sunflower & 33706 & 23 \\
\hline - $\quad$ Peanut & 6650 & 15 \\
\hline Fodders of which: & 46440 & 2369 \\
\hline - Bersim & 30453 & 1717 \\
\hline - Corn & 11997 & 555 \\
\hline Pulses & 25840 & 20 \\
\hline Early fruit and vegetables including : & 1168 & 32 \\
\hline - Strawberries tree & 660 & 28 \\
\hline - Raspberry bush & 102 & 1,2 \\
\hline - $\quad$ Blueberry & 276 & 1,7 \\
\hline - $\quad$ Asparagus & 50 & 0,3 \\
\hline - $\quad$ Green beans & 80 & 1,0 \\
\hline Banana tree & 3688 & 152 \\
\hline Avocado tree & 1166 & 11 \\
\hline
\end{tabular}

\subsection{Methodological approach followed}

\subsubsection{Selection of the sample of holdings to be investigated}

The objective of this study is to contribute to the improvement of the population's health and the preservation of the environment. Its also permit to identify the pesticide formulations used by the producers.

To cover the lack of data from field surveys of farmers, surveys of pesticide resellers have been conducted in 2016/2017 and 2017/2018 crop seasons. The samples are taken from 100 farms, mainly in the coastal area of the Gharb plain, especially in the southern part of the Merja Zerga watershed (Mnasra water table and Gharb water table). The farms contain crops such as Citrus, Tomato, Strawberry, Banana and Raspberry. The sample has chosen based on criteria of the natural environment, the distribution of different crops, the additional value of crops, etc (Figure 2)

During this phase, that lasts about two years; the primary data has collected and used in the calculation of the indicator TFI).

The data is listed in two types of survey cards (farmer and supplier) that contain information mainly on: Trade name; Active ingredient; Farmer and its location; Crops at the farm level; Crop Rotation; Dose applied by farmers for each product; Supplier and location; Crops for each product; Prescribed Application Rate for each product. This study allows us to identify and calculate an indicator of the frequency of treatment caused by pesticides, especially on the environment. 


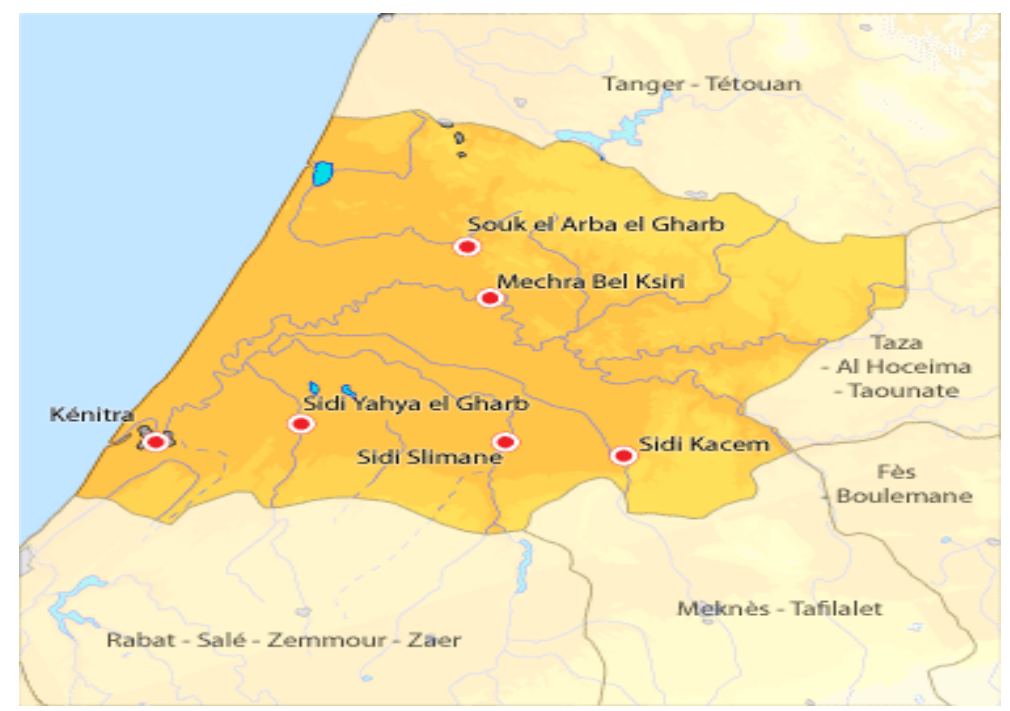

Figure 2. Map showing the study area (ORMVAG, 2017)

According to these surveys, we can identify the agglomeration locations of the pesticide resellers and the different main crops grown in our sample; we are also able to identify the different types of pesticides sold in the area, as well as the adopted quantities by farmers and the prescribed doses for each product.
In total, 71 resellers of plant protection products are identified in the survey area (Figure 3).

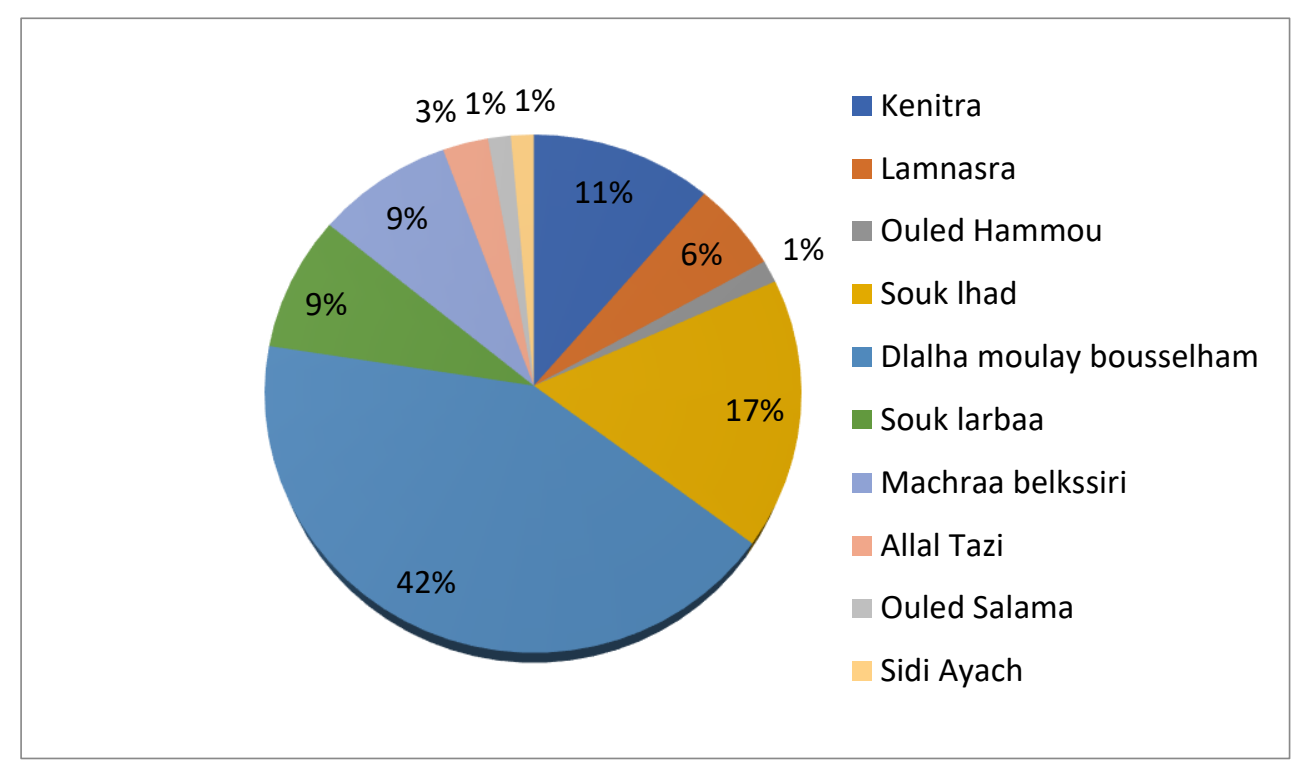

Figure 3. Distribution of pesticide resellers in the study area (in number)

The majority of resellers are concentrated in the rural communes located in the coastal area of Gharb such as Dlalha Moulay Bousselham (42\%) Souk el Had $(17 \%)$ and Kenitra (11\%) which serve mainly the areas where there is more concentration of the most pesticide-consuming crops

\section{Results and discussions}

\subsection{Technical-economic description of agricultural practices}

Presentation of the crop rotations

The 100 surveys carried out in the study area covering a total surface of 555 ha; the area is characterized by different types of irrigation (drip, sprinkler, or gravity) and a practice of several irrigation systems culture.

Concerning the crops grown in the sample, it is noted that the citrus fruits with the tomato crop are the most dominant crops. Where the citrus crop covers, an area of 132 ha and tomato crop covers an area of 115ha, followed by red berries, especially strawberry crop that covers an area of 78 ha. Then comes the avocado which covers an area of 11 ha, the banana and raspberry crops are also present in the study area, and cover respectively $8 \%$ and $5 \%$ of the total surface. The different speculations are presented in (Table 3). 
Table 3. Different crops with their areas in (ha) and (\%).

\begin{tabular}{|c|c|c|c|}
\hline Category & Culture & Cultivated area in (ha) & Percentage $(\%)$ \\
\hline industrial crops & Sugar cane & 37 & 7 \\
\hline \multirow{5}{*}{ market gardening } & eggplant & 13 & 2 \\
\hline & cauliflower & 4 & 1 \\
\hline & pepper & 20 & 4 \\
\hline & Melon & 10 & 2 \\
\hline & Tomato & 115 & 21 \\
\hline forage crops & forage corn & 12 & 2 \\
\hline \multirow{5}{*}{ fruit crops } & Banana tree & 46 & 8 \\
\hline & Citrus & 132 & 24 \\
\hline & Strawberries tree & 78 & 14 \\
\hline & Raspberry bush & 25 & 5 \\
\hline & Avocado tree & 63 & 11 \\
\hline \multicolumn{2}{|c|}{ Total } & 555 & 100 \\
\hline
\end{tabular}

\subsection{Characterization and quantification of} phytosanitary products used

\subsubsection{Characteristics and types of plant} protection products used

The survey of the 100 farms in the study area completed by the survey among the 71 retailers interviewed revealed that, among the 593 registered trademarks of plant protection products at the national level, the use of 109 types, containing 77 different active ingredients, is identified. These products are distributed as follows: 54 fungicides (50\%), 35 insecticides (32\%) and the remaining 20 are of the herbicide types, which represents 18 (Figure 4):

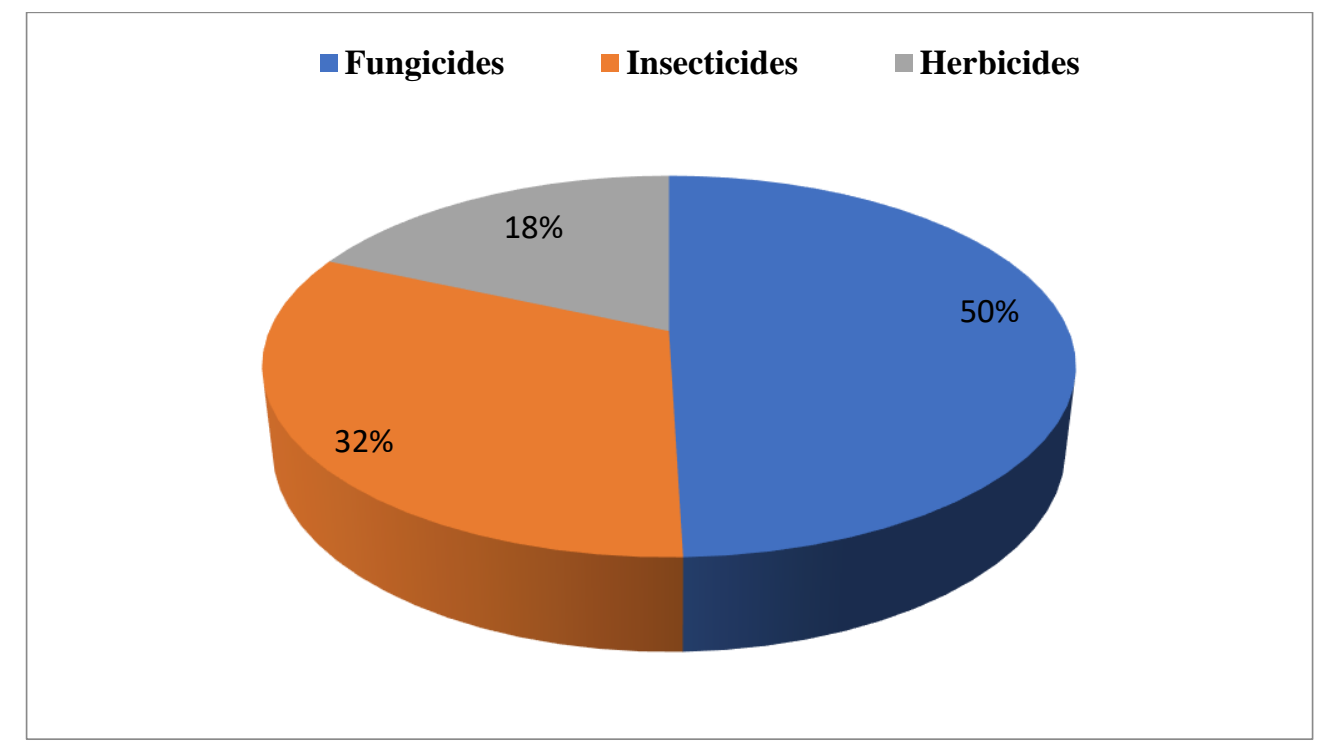

Figure 4. Distribution of the types of pesticides used in the study area (in quantity)

\subsubsection{Fungicides}

Of the 264 fungicide varieties registered and marketed nationally, there are 54 products in the study area. These products contain 39 different active ingredients with one active ingredient per product for 39 varieties, and the other 15 combine 2 active ingredients at a time.
The most frequently encountered active ingredients are Mancozeb, Copper, Metalaxyl, ThiophanateMethyl, Carbendazime, which correspond to each of the trade names (Table 4): 
Table 4. Characteristics of the fungicides used at the level of the farms surveyed.

\begin{tabular}{|c|c|}
\hline Trade Name & Active ingredient \\
\hline Acrobat cu & oxychlorure de cuivre, dimethomorphe \\
\hline Acrobat mz wp & Mancozèbe \\
\hline Acrobat wg & Mancozèbe, dimethomorphe \\
\hline Actamyl 70 wp & Thiophanate-méthyl \\
\hline Agrezate & Mancozèbe \\
\hline Aliette Flash & Fosétyl-Aluminium \\
\hline Antracol 70 wp & Propinebe \\
\hline Armetil m & Mancozèbe, metalaxyl \\
\hline Artea $330 \mathrm{EC}$ & Propiconazole+Cyproconazole \\
\hline Balear $720 \mathrm{sc}$ & Chlorothalonil \\
\hline Banco plus & Chlorothalonil \\
\hline Champion & Cuivre-hydroxyde de cuivre \\
\hline cobox & Cuivre \\
\hline Coragen & Chlorantraniliprole \\
\hline Cropzim 500 sc & Carbendazime \\
\hline Cuivrol $50 \%$ wp & Cuivre \\
\hline Cuivroxine & oxyquinoleate de cuivre \\
\hline Cupra-50 & Cuivre-oxyde de cuivre \\
\hline Cuprene 50 & Cuivre-oxychlorure de cuivre \\
\hline Cuprozin & Cuivre \\
\hline Curator & Azoxystrobine+Chlorothalonil \\
\hline Daconil $720 \mathrm{Sc}$ & Chlorothalonil \\
\hline Difcor $250 \mathrm{ec}$ & Difenoconazole \\
\hline Dithan M 45 & Mancozèbe \\
\hline Equation pro & famoxadone \\
\hline Flare gold & Cuivre, metalaxyl-m \\
\hline Flint $50 \mathrm{WG}$ & Trifloxystrobine \\
\hline Folio gold 537,5 & metalaxyl-m \\
\hline fongicuivre & Cuivre \\
\hline Fungomil 72 wp & Mancozèbe \\
\hline Galben M & Bénalaxyl+Mancozèbe \\
\hline Gardner & Difenoconazole \\
\hline Impact RM & Flutriafol+Carbendazime \\
\hline Laskor 50 PM & Carbendazime \\
\hline Mancofil & Mancozèbe \\
\hline Maneb 80 & Manebe \\
\hline Maxil m & Mancozèbe, metalaxyl \\
\hline Miracle & Mycolobutanil \\
\hline Ortiva $25 \mathrm{EC}$ & Azoxystrobine \\
\hline Pelt 44 PM & Thiophanate-méthyl \\
\hline
\end{tabular}




\begin{tabular}{|c|c|}
\hline Pride $200 \mathrm{sc}$ & fenazaquin \\
\hline Pyrus & Pyrimethanil \\
\hline Ridomil Gold MZ $68 \mathrm{WG}$ & Mancozèbe+Méfénoxame \\
\hline Rugby $10 \mathrm{~g}$ & Cadusafos (10\%) \\
\hline Score $250 \mathrm{ec}$ & Difenoconazole \\
\hline Signum WG & Boscalid+Pyraclostrobine \\
\hline Switch $62.5 \mathrm{WG}$ & Cyprodinil+Fludioxonil \\
\hline Systhane $12 \mathrm{E}$ & Myclobutanil \\
\hline Teldor $50 \mathrm{WG}$ & Fenhexamid \\
\hline Thiogri 70 & Thiophanate-méthyl \\
\hline Topas $100 \mathrm{ec}$ & Penconazole \\
\hline Turbo $\mathrm{ZM}$ & Mancozèbe \\
\hline Uthane $80 \% \mathrm{WP}$ & Mancozèbe \\
\hline Vydate $10 \mathrm{~g}$ & Oxamyl (10\%) \\
\hline
\end{tabular}

It is important to note also that some of these products have the characteristic of having a wide range of protection because they are used for both market gardening and fruit growing.

\subsubsection{Insecticides}

Out of 208 commercial varieties of registered insecticides and miticides, only 35 are available in this study area. These products mark the presence of 21 different active ingredients, of which only one is composed of two substances.

The most dominant types of active ingredients are Abamectin, Cyperméthrine and Chlorpyriphos-éthyl. For each designation of insecticide, a marketed active ingredient is illustrated as follows (Table 5):

Table 5. Characteristics of the insecticides used at the level of the farms surveyed.

\begin{tabular}{|c|c|}
\hline Trade Name & Active ingredient \\
\hline Acaritouch & Propylene glycol monolaurate \\
\hline Acramite $480 \mathrm{sc}$ & Bifenzanate \\
\hline Actara $25 \mathrm{WG}$ & Thiamétoxam \\
\hline Arrivo $25 \mathrm{EC}$ & Cyperméthrine \\
\hline Avaunt $150 \mathrm{EC}$ & Indoxacarbe \\
\hline Berlina & Abamectin \\
\hline Coragen & Chlorantraniliprole \\
\hline Cypermethrine 25 & Cyperméthrine \\
\hline Decis expert & Deltamethrine \\
\hline Dursban 4 & Chlorpyriphos-éthyl \\
\hline Dursban $75 \mathrm{WG}$ & Chlorpyriphos-éthyl \\
\hline Express & Thiamétoxam \\
\hline Karaté 2 & Lambda-cyhalothrine \\
\hline Karaté 5 ec & Lambda-cyhalothrine \\
\hline Kendor $70 \mathrm{wp}$ & Imidacloprid \\
\hline Lannate $20 \mathrm{~L}$ & Méthomyl \\
\hline Lannate 25 ec & Méthomyl \\
\hline Limocide & Essence d'orange \\
\hline Mesurool $50 \mathrm{WP}$ & Mercaptodiméthur \\
\hline
\end{tabular}




\begin{tabular}{|c|c|}
\hline Mocap $10 \mathrm{G}$ & Ethoprophos \\
\hline Pilori $480 \mathrm{EC}$ & Chlorpyriphos-éthyl \\
\hline Pirate $50 \mathrm{sc}$ & Chlorantraniliprole \\
\hline Pride $200 \mathrm{sc}$ & Fenazaquin \\
\hline Proclaim $05 \mathrm{SG}$ & Enamectin benzoate \\
\hline Promethion & Diméthoate \\
\hline Robust $48 \mathrm{ec}$ & Chlorpyriphos-éthyl \\
\hline Rugby $10 \mathrm{G}$ & Cadusafos \\
\hline Salvador $25 \mathrm{wp}$ & Méthomyl \\
\hline Synergy & Chlorpyriphos+cyperméthrine \\
\hline Takumi $20 \mathrm{wg}$ & Flubendiamide \\
\hline Tarique $25 \mathrm{ec}$ & Cyperméthrine \\
\hline Ustaad & Cyperméthrine \\
\hline Valmec & Abamectin \\
\hline Vertico $18 \mathrm{EC}$ & Abamectin \\
\hline Vertimec $18 \mathrm{EC}$ & Abamectin \\
\hline
\end{tabular}

Concerning the common uses of these insecticides, it is noted that the majority of these pesticides are intended mainly for the treatment of market garden crops and banana plants.

\subsubsection{Herbicides}

For herbicides, only 20 varieties are used in this zone among 121 registered trade names. These 20 products contain 17 different active ingredients so that 6 of them contain 2 ingredients, while 2 marks contain 3 ingredients.

The most frequently encountered active ingredients are 2,4-D (exist in 5 products) and the MCPA (exist in 2 products). The (Table 6) présents the détail of differents listed herbicides.

Table 6. Characteristics of the herbicides used at the level of the farms surveyed.

\begin{tabular}{|c|c|}
\hline Trade Name & Active ingredient \\
\hline Afalon $50 \mathrm{wp}$ & Linuron \\
\hline Al Fahd mix & 2,4 D (acide sels ammonium)+MCPA \\
\hline Arzin $75 \mathrm{wg}$ & Metribuzine \\
\hline Atlantis & Odosulfuron-methyl-sodium \\
\hline Boxer & Prosulfocarbe \\
\hline Daka 50 wp & Linuron \\
\hline El Afrit 200 & 2,4 D (ester butylglycol) \\
\hline Faucil & Linuron \\
\hline Gallant super & Haloxyfop-R méthyl \\
\hline Gramoxone & Paraquat \\
\hline Hussar evolution & $\begin{array}{l}\text { Fénoxaprop-ethyl+Indosulfuron sodium+Mefenpyr } \\
\text { diethyl }\end{array}$ \\
\hline Imidafor 4 & Glyphosate+Sel d'ammonium \\
\hline Lumax 537.5 SE & Mesotrione+s. métolachlore+terbutylazine \\
\hline Matecor & Metribuzine \\
\hline Menjel 24 EC & 2,4 D (ester butylglycol) \\
\hline Mustang 306 SE & 2,4 D (équivalent acide)+Florasulam \\
\hline
\end{tabular}




\begin{tabular}{|c|c|}
\hline Ovni XL & Glyphosate+Oxyfluorfen \\
\hline Printazol 75 & 2,4 D+MCPA \\
\hline Prolinuron & Linuron \\
\hline Topik 080 EC & Clodinafop propagyl+ Cloquintocel méxyl (safener) \\
\hline
\end{tabular}

It should also be noted that these products - by their constitution - have proved their effectiveness not only for a single category of cultivation but for various speculations threatened by weeds (strawberry trees, eggplants, tomatoes ...).

3.2.1.4. Quantities of phytosanitary products used An amount of $7569,8 \mathrm{~kg}$ of pesticides is spilt in the 100 farms in our survey and covers an area of 555ha; (considering the density of the products equal to 1 with the division of the total quantity discharged of $7569.8 \mathrm{~kg}$ over the total area surveyed of 555ha, the average is $13.6 \mathrm{~kg} / \mathrm{ha}$ per farm). A value that exceeds two and a half times the average pesticide consumption in France, which is $5,4 \mathrm{~kg} / \mathrm{ha}$ (the largest consumer in Europe and the fourth largest consumer in the world) ${ }^{8}$.

- A quantity of $3179,3 \mathrm{~kg}$ of fungicides is used in an area of $360 \mathrm{ha}$, with an average of $8,8 \mathrm{~kg}$ of fungicides/ha per treated area and an average of $5,7 \mathrm{~kg}$ of fungicides/ha per farm.

- The application of $2422,3 \mathrm{~kg}$ of insecticides in an area of 506 ha, with an average of $4,8 \mathrm{~kg}$ insecticide/ha per treated area and an average of $\mathbf{4 , 4}$ kg of insecticides/ha per farm.

- The application of $1968,2 \mathrm{~kg}$ of Herbicides in an area of $535 \mathrm{ha}$, with an average of $3,7 \mathrm{~kg}$ of herbicides/ha per treated area and $3,5 \mathbf{k g}$ of herbicides/ha per farm, a quantity which is considered small compared to the quantity of other types of pesticides and it's explained by the farmers' use of manual grubbing weeds.

\subsubsection{Quantities used by each crop}

The banana crop, which occupies only $8 \%$ of the study area (46ha), consumes an average of $47,5 \mathrm{~kg} / \mathrm{ha}$, which makes a big pressure on the soil and soil resources. The banana crops come as second in terms of water consumption.

The major banana diseases are presented as follows: Nematodes (Meloidogyne and Radopholus); cryptogamic diseases which are caused mainly by two types of fungi (Verticillium theobromae, botrytis spp); virus diseases such as cucumber mosaic virus, as well as diseases caused by other parasites such as, mites and defoliating caterpillars. Citrus (mainly orange) comes in the second position concerning the pressure on resources and in the first position in terms of the global quantity consumed by each crop with a total of $2204,4 \mathrm{~kg}(29,1 \%)$. Strawberry cultivation which covers $78 \mathrm{ha}$, consumes a moderately low amount compared to the previous two crops, with a total of $491,4 \mathrm{~kg}, 6,5 \%$ of the total amount of pesticides applied with an average of $6,3 \mathrm{~kg} / \mathrm{ha}$, this can be explained, by the regulation that surrounds the use of pesticides for crops intended for export.

The details of average quantities used for the main crops identified are presented in (Figure 5) and (Figure 6).

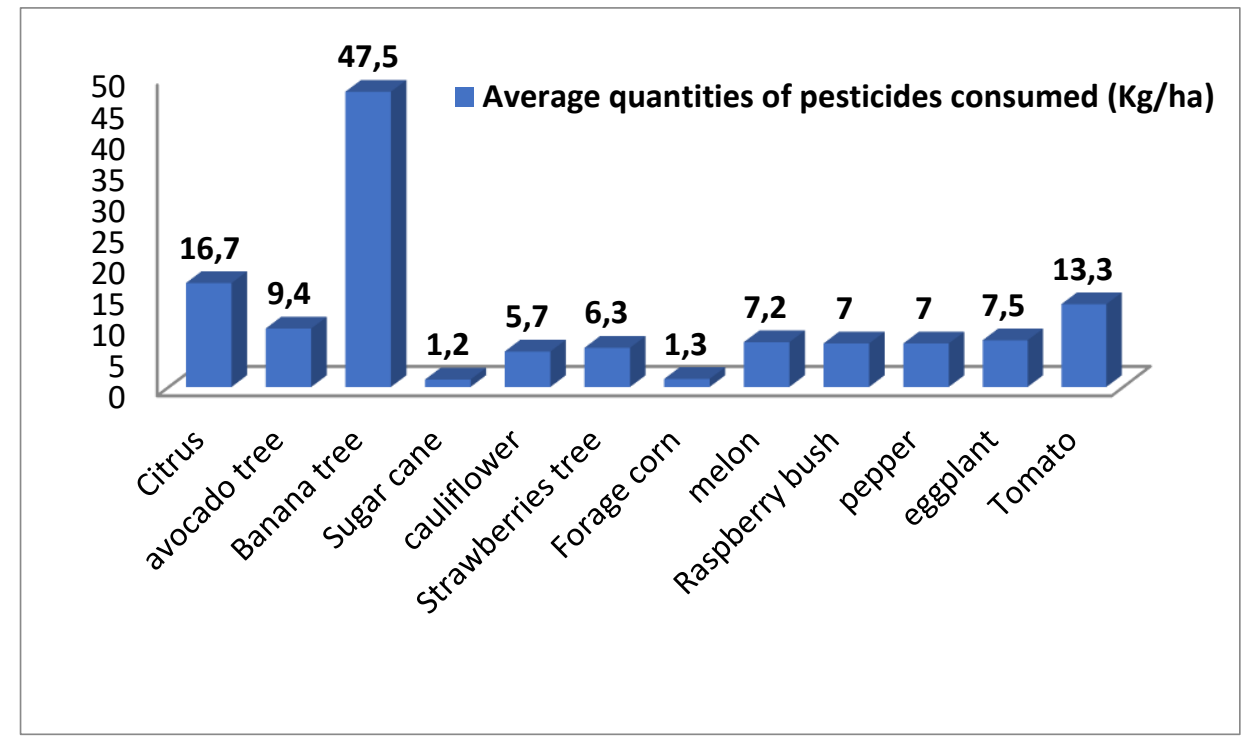

Figure 5. Average quantities of pesticides used by crops at the level of the farms surveyed (Kg/ha) 


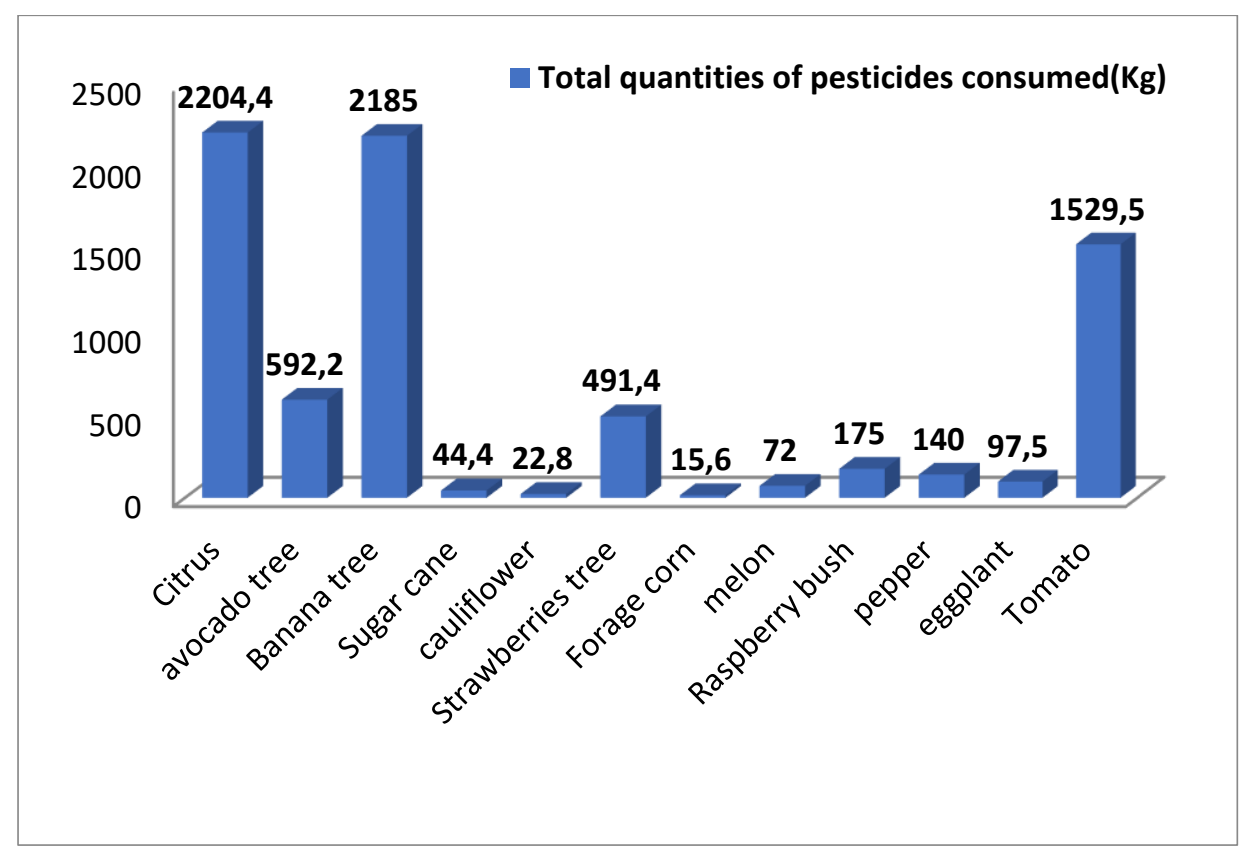

Figure 6. Total quantities of pesticides used by crops at the level of the farms surveyed (Kg)

\subsection{Treatment Frequency Indicator (TFI)}

The Treatment Frequency Indicator (TFI) determines the frequency of treatment, which is the number of registered pesticide doses applied to a field during a crop cycle ${ }^{9}$. The registered dose is defined as the effective application rate of a product on a given crop and target organism.

As a result, the TFI reflects the intensity of use of the phytosanitary products, or "phytosanitary pressure" exerted on the plot and the environment; as well as the dependence of farmers on these products ${ }^{10}$. For each crop and different geographical areas, a maximum reference TFI was defined.

The TFI is calculated from two national databases ${ }^{11}$.

- The first database (phytosanitary index) that allows associating each commercial product with the "approved dose" that will be used in the calculation of the TFI.

- The second base ("Cultural Practices" Survey), which gives precise indications on agricultural practices, technical itineraries, the use of phytosanitary products "applied doses", on a chosen sample to reflect the dominant crops on the studied territory.
In general: $\mathrm{TFI}=($ applied dose $/$ approved dose $)$

This TFI can be calculated for a parcel, a farm or a territory, or a large category of products or a given crop ${ }^{5}$.

\subsection{Comparative analysis of the phytosanitary pressure}

The analysis of the average variation in treatment frequency indicators related to the different crops grown in a study area is not easy; it depends mostly on the amount of pesticides applied for plant protection against various attacks that differ considerably from one technical route to another and from one crop category to another.

Indeed, the production of bananas depends significantly on the use of a wide range of pesticides including fungicides and insecticides and with a high dose, resulting in a high phytosanitary pressure of 38 (Figure 7). This ranking is relatively the same as that found by authors of studies $7,9,11,18-21$, except that the frequency differs, from where the banana investigated at this level recorded an average of 14 which generates a lower pressure, as well less than that recorded by EL Azzouzi et al. ${ }^{8,9,12,20}$ who have registered a banana TFI value of 48 . 


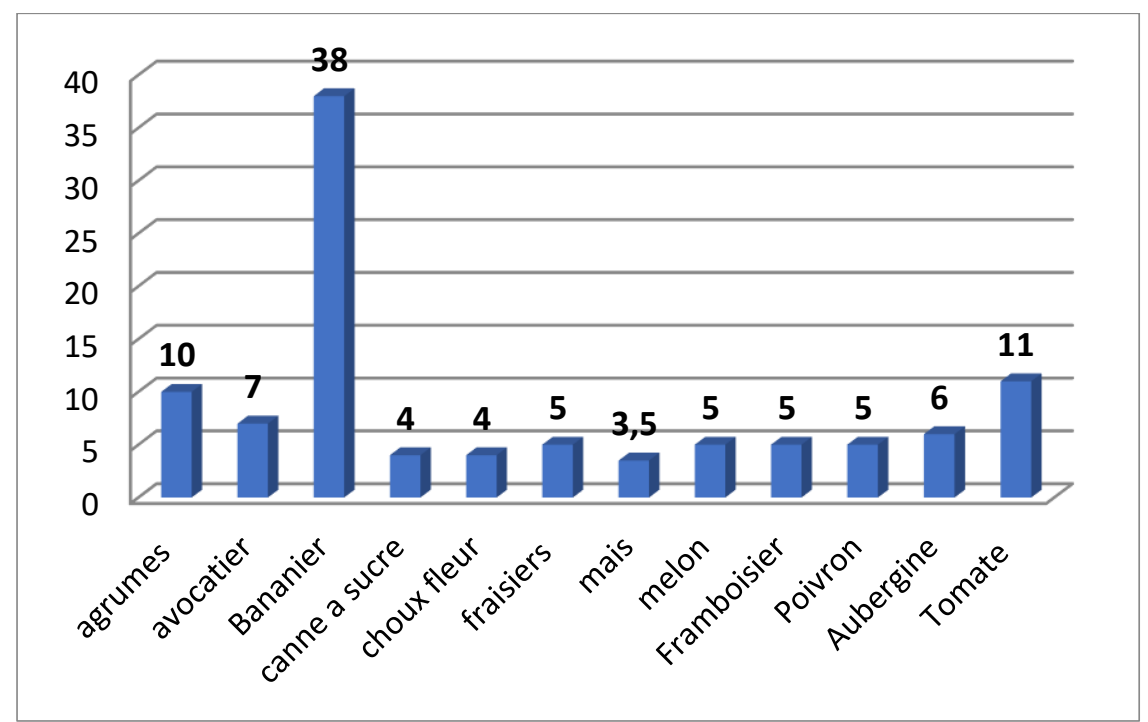

Figure 7. Treatement Frequency Indicatorde of different cultures in the study area (TFI crop)

The Banana crop is followed by tomato crop, which is one of the most pesticide-eating vegetable crops, because of its highly susceptible nature to insect pests, compared to the value recorded in France, which uses $5 \%$ of pesticides for the treatment of pests ${ }^{9}$. It, therefore, generates a phytosanitary pressure of around 11 . The ranking for this crop is considered the same as that found by other authors ${ }^{8,19,22}$ except in terms of the value of the TFI, with a registered value of 9 .

Tree crops, are treated with a large amount of pesticides for agricultural use, and generate a high pressure of pesticide use (orange tree TFI $=10$ and avocado tree $\mathrm{TFI}=7$ ), represent almost the half of fruit crops in France ${ }^{9,13,17}$ with a value of 17 . Note also that in other studies ${ }^{8,10,14,13,22}$, the orange tree records a value of 8 as TFI, which is relatively low compared to our sample.

The so-called high-end crops, whose production is intended for export exert a pressure generally less strong, because of an excellent technical and cultural conduct. In respectful health and environmental framework: the strawberry, for example, generates a pressure of about 5, equal to the raspberry tree that recorded an indicator of 5, values relatively similar to those found by El Azzouzi et al. ${ }^{8,15,17,18,21}$.

\section{Conclusion}

The inventory of pesticides used in this study, which covers a surface of 555ha, shows the presence of 109 types with 77 different active ingredients, which are sold mainly by 71 resellers. These products contain 54 fungicides, 35 insecticides, and the remaining 20 are of the herbicide type, where bananas and tomatoes rank first in terms of pesticide consumption. In addition, the analysis of data on the various environmental impacts of pesticide, by using the treatment frequency indicator (TFI), reveals that banana, orange and tomato crops are the most phytosanitary treatment on the environment with a high TFI compared to other crops grown in the same study area.

Generally, the major problem in this zone is the risk of deterioration of the natural environment with all its resources of water and soil.

\section{Recommendations}

To better achieve the objectives of this study, we recommend the strengthening of the pesticides control to avoid the use of unregistered products. Training sessions should take place with the support of concerned Ministries and civil society. Besides sensibilizing farmers about pesticide hazards, and the benefit by the use of good agricultural practices and technical mechanisms for pesticide, as well as the respect of prescribed doses for each product.

\section{Acknowledgements}

Authors are especially grateful to acknowledge the Department of agricultural development and also would like to thank all the staff of ORMVAG for their kind help in sampling collection.

\section{Conflict of interests}

The authors declare that there is no conflict of interests regarding the publication of this paper.

\section{References}

1- M. Faure, La sécurité sanitaire du consommateur de fraises marocaines : deux poids, deux mesures ? Confluences Mediterranee, 2019, 1, 149-65.

2- R. Harbouze, J. P. Pellissier, J. P. Rolland, W. Khechimi, Rapport de synthèse sur l'agriculture au Maroc, 2019.

3- A. Naamane, A. Sadiq, A. Belhouari, N. Iounes, S. EL Amrani, Enquête sur l'utilisation des engrais et pesticides chez les agriculteurs de la région de Casablanca-Settat. Revue Marocaine 
des Sciences Agronomiques et Vétérinaires, 2020,8.

4- A. A. Houssa, S. Drissi, A. Asfers, L. Oubaki, Z. Haddouche, F. Amlal, H. Chraibi, Éléments d'aide au contrôle de gestion et au management de l'agrumiculture au Maroc. Revue Marocaine des Sciences Agronomiques et Vétérinaires, 2020, 8.

5- A. Biarnès, P. Andrieux, J. M. Barbier, A. Bonnefoy, C. Compagnone, X. Delpuech, C. Gary, A. Metay, J. P. Rellier, M. Voltz, Evaluer par modélisation des stratégies de réduction des usages d'herbicides dans les bassins versants viticoles, Innovations Agronomiques, 2017, 57, 141-152.

6- M. Cerf, M. Barbier, M. H. Jeuffroy, A. Cardona, M. Le Bail, L. Prost, A. de Marguerye, J. Masson, E. Merot, B. Omon, La transition vers la réduction de l'usage des pesticides au prisme de l'intermédiation, Innovations Agronomiques, 2017, 59, 133-146.

7- K. El Ouedghiri, N. Badrane, S. Maniar, F. ElAkhal, F. O. Chahdi, A. E. O. Lalami, Evaluation of chronic intoxication by organophosphate insecticides among hygiene workers in the city of Fez, Morocco, Archives des Maladies Professionnelles et de l'Environnement, 2016, 77, 756-765.

8- E. H. EL Azzouzi, H. E. Bouzaidi, K. Nouri, M. E. Azzouzi, M. Fekhaoui, Study the impact of pesticides using pressure indicator and toxicity watershed Merja Zerga (Morroco), Advances in Environmental Biology, 2014, 8, 31-35.

9- R. A. Ouédraogo, F. C. Kambiré, M. P. Kestemont, C. L. Bielders, Caractériser la diversité des exploitations maraîchères de la région de Bobo-Dioulasso au Burkina Faso pour faciliter leur transition agroécologique, Cahiers Agricultures, 2019, 28, 20.

10-N. Dubreuil, M. M. Ottomani, G. Tison, P. Kreiter, Réduction des intrants phytosanitaires en vergers de kiwis et de clémentines en Corse, Innovations Agronomiques, 2018, 70, 87-104.

11-C. Albert, C. Galler, J. Hermes, F. Neuendorf, C. Von Haaren, A. Lovett, Applying ecosystem services indicators in landscape planning and management: The ES-in-Planning framework, Ecological Indicators, 2016, 61, 100-113.

12-C. V. Dooren, H. Aiking, P. Vellinga, In search of indicators to assess the environmental impact of diets, The International Journal of Life Cycle Assessment, 2018, 23, 1297-1314.

13-L. D. Głowacka, M. Janecki, D. Dybowski, B. Szymczycha, H. Obarska-Pempkowiak, E. Wojciechowska, P. Zima, S. Pietrzak,
G. Pazikowska-Sapota, B. Jaworska-Szulc, A. Nowicki, A new approach for investigating the impact of pesticides and nutrient flux from agricultural holdings and land-use structures on Baltic Sea coastal waters, Polish Journal of Environmental Studies, 2019, 28, 2531-2539.

14-S. Knillmann, P. Orlinskiy, O. Kaske, K. Foit, M. Liess, Indication of pesticide effects and recolonization in streams, Science of the total environment, 2018, 630, 1619-1627.

15-I. Vardopoulos, S. Falireas, I. Konstantopoulos, E. Kaliora, E. Theodoropoulou, Sustainability assessment of the agri-environmental practices in Greece. Indicators' comparative study, International Journal of Agricultural Resources, Governance and Ecology, 2018, 14, 368-399.

16-I. Berni, Pesticide Use Pattern among Farmers in a Rural District of Meknes: Morocco, Open Access Library Journal, 2016, 3, 1.

17-L. Cretin, A. Triquenot Apports de produits phytopharmaceutiques en arboriculture : nombre de traitements et indicateur de fréquence de traitements. Campagne agricoles 2015 et 2012, 2018.

18-F. Le Bellec, M. Scorbiac, J. Sauzier, Les pratiques phytosanitaires des producteurs de légumes de l'île Maurice : impacts et perspectives de changement, Cahiers Agricultures, 2017, 26.

19-L.Guichard, F. Dedieu, M. H. Jeuffroy, J. M. Meynard, R. Reau, I. Savini, Le plan Ecophyto de réduction d'usage des pesticides en France: décryptage d'un échec et raisons d'espérer, Cahiers Agricultures, 2017, 26, 14002.

20-J. E. Primost, D. J. Marino, V. C. Aparicio, J. L. Costa, P. Carriquiriborde, Glyphosate and AMPA, "pseudo-persistent" pollutants under realworld agricultural management practices in the Mesopotamic Pampas agroecosystem, Argentina, Environmental Pollution, 2017, 229, 771-779.

21-C.Renaud-Gentié, V. Dieu, M. Thiollet-Scholtus, M. H. G. van der Werf, A. Perrin, A. Mérot, L'Analyse du Cycle de Vie pour réduire l'impact environnemental de la viticulture biologique. In BIO Web of Conférences, 2019, 15, 01031.

22-L. Mamy, L. Alletto, C. Bedos, P. Benoit, E. Justes, S. K. D. Lammoglia, J. M. MarínBenito, N. Munier-Jolain, B. Nicolardot, V. Pot, M. Ubertosi, Evaluation et comparaison des impacts sur l'environnement et la santé des pesticides utilisés dans des systèmes de culture conventionnels et innovants: synthèse des résultats du projet ECoPESt, 2017. 